\title{
ATTITUDES TOWARDS GENETICALLY MODIFIED ORGANISMS IN SLOVENIA: BETWEEN KNOWLEDGE AND MYTHS STALIŠČA DO GENETSKO MODIFICIRANIH ORGANIZMOV V SLOVENIJI: POZNAVANJE IN MITI
} Karmen Erjavec ${ }^{1}$, Jožica Zajc ${ }^{1}$, Melita Poler Kovačič', Jelka Šuštar Vozlič², Samo Uhan', Luka Juvančičs

\author{
Prispelo: 22. 4. 2012 - Sprejeto: 7. 1. 2013
}

Original scientific article UDC 604.6:316.654(497.4)

\begin{abstract}
Objective: Because existing studies examining the impact of knowledge on people's attitudes towards genetically modified organisms (GMOs) have had contradictory results, the goal of this study was to explore the attitudes that the population of Slovenia has towards GMOs and how knowledge affects their attitudes.

Methods: In January 2012, a telephone survey was conducted researching attitudes towards GMOs and knowledge about them on a representative sample of the population of Slovenia $(N=446)$.

Results: The results revealed a predominantly negative attitude towards GMOs, regardless of their type, application and geographical distance; perceptions of the negative impact of GMOs on an individual's health were particularly strong. The majority of respondents (59.5\%) had moderate knowledge about GMOs, while a largeshare (30.4\%) had poor knowledge of the topic. They had better objective knowledge about topics linked to formal education or legislation and a weaker understanding of mass media myths. Correlation analysis and one-way analysis of variance showed a statistically significant correlation between knowledge and attitudes towards GMOs. The respondents with better objective knowledge (who gave the correct answers to test questions) had a less firm and a more positive attitude towards GMOs and vice versa. The respondents who lacked objective knowledge but expressed subjective knowledge (they were convinced that their answers were correct) on average had a more negative attitude towards GMOs compared to those who lacked subjective knowledge.

Conclusions: This finding leads to the conclusion that knowledge, particularly relating to media myths about GMOs, has an important role in forming attitudes towards the impact of GMOs on an individual's health.
\end{abstract}

Key words: genetically modified organisms, attitudes, objective knowledge, subjective knowledge, Slovenia

Izvirni znanstveni članek UDK 604.6:316.654(497.4)

\section{Izvleček}

Namen: Zaradi nasprotujočih si izsledkov obstoječih raziskav o vplivu znanja na stališča o GSO je bil namen študije ugotoviti, kakšna so stališča prebivalcev Slovenije do gensko spremenjenih organizmov (GSO) in kako znanje vpliva na stališča o GSO.

Metode: V januarju 2012 je bila izvedena telefonska anketa o stališčih in znanju o GSO na reprezentativnem vzorcu med prebivalci Slovenije $(N=446)$.

Rezultati: Izsledki so pokazali prevladujoče negativno stališče do GSO ne glede na vrsto, uporabo in na zemljepisno oddaljenost; pri tem posebej izstopa percepcija vpliva GSO na posameznikovo zdravje. Večina anketiranih (59,5 \%) ima o GSO srednje dobro znanje; visok delež $(30,4 \%)$ je takih, katerih znanje je slabo. Boljše objektivno znanje imajo o temah iz formalnega izobraževanja ali spremljanja zakonodaje, slabše pa o medijskih mitih. Korelacijska analiza in enosmerna analiza variance sta pokazali, da med znanjem in stališči o GSO obstaja statistično značilna povezanost. Anketiranci z boljšim objektivnim znanjem (pravilni odgovori na testna vprašanja) imajo manj trdno in bolj pozitivno stališče do GSO in nasprotno. Anketiranci brez objektivnega znanja, a z izraženim subjektivnim

\footnotetext{
${ }^{1}$ University of Ljubljana, Faculty of Social Sciences, Kardeljeva ploščad 5, 1000 Ljubljana, Slovenia

${ }^{2}$ Agricultural institute of Slovenia, Haquetova ulica 17, 1000 Ljubljana, Slovenia

${ }^{3}$ University of Ljubljana, Biotechnical faculty, Department of Animals Science, Groblje 3, 1230 Domžale, Slovenia

Correspondence to: e-mail: karmen.erjavec @ fdv.uni-lj.si
} 
znanjem (prepričanost o pravilnosti svojih odgovorov) imajo v povprečju bolj negativna stališča do GSO kot tisti, ki nimajo subjektivnega znanja.

Zaključki: To pomeni, da ima znanje, še posebej pa medijski miti o GSO, pomembno vlogo pri oblikovanju stališča o vplivu GSO na posameznikovo zdravje.

Ključne besede: gensko spremenjeni organizmi, GSO, stališča, objektivno znanje, subjektivno znanje, Slovenija

\section{INTRODUCTION 1}

Over the last decades, few topics from the interdisciplinary field of biotechnology have attracted as much attention in the public sphere and in the media as genetically modified organisms (GMOs) (1). GMOs remain a subject of public concern or even disapproval, especially in the field of public health (2), although food (and feed) consisting of, containing or produced from GMOs should undergo a rigorous safety assessment procedure before being placed on the market within the Community ( 3 , 4). Public health concerns over the production and consumption of transgenic organisms appear to be posing worries among Europeans, especially regarding unintended health impacts from GMOs related to allergens, antibiotic resistance, decreased proteins and toxins (2). Public opinion surveys on GMOs (5, 6) have shown that the majority of Europeans are opposed to GMOs, particularly in food, while they have less difficulty with the concept of using GMOs in medicine. The longitudinal Eurobarometer surveys indicate an increasing share of opponents to genetically modified (GM) food. In the last survey from 2010, 61\% of Europeans were opposed to and $23 \%$ were accepting of GM food (6). Compared to the European average, Slovenians expressed a lower level of approval for GM food; in 2010 , only $21 \%$ of Slovenians viewed GM food as acceptable (6). The majority of Europeans (62\%) approve of using GMOs in pharmacy and medicine, while $27 \%$ are opposed to it (5). Compared to the European average, Slovenians are also more sceptical towards using GMOs in the health sector; however, there are more supporters (53\%) than opponents (36\%) (5). The negative attitude towards GMOs has been confirmed by all public opinion surveys on GMOs in Slovenia (7-9), which showed that Slovenians hold a negative attitude towards GMOs, particularly GM food. A survey conducted by ZPS (9) revealed that $79.4 \%$ of Slovenians are worried about the impact of GM food on health.

Although some authors argue that better knowledge increases the acceptance of biotechnology (10) and that a negative attitude is connected to a lack of knowledge (11), other authors claim that better knowledge about GMOs does not necessarily increase positive attitude towards them $(8,12)$ but instead encourages the forming of clearer attitudes, positive or negative, in accordance with information received (13). Better knowledge and understanding of biotechnology can even polarise and strengthen the existing attitudes towards GMOs (14). In fact, according to some studies, both the advocates and the opponents of GMOs have better knowledge about GMOs than individuals who are indifferent $(15,16)$. Some authors have found that a potential explanation for these differences in conclusions about the impact of knowledge on attitudes towards GMOs is the manner and type of knowledge measured. They differentiate between subjective knowledge (an individual's perception of how much he/she knows) and objective knowledge (how much an individual actually knows) (17). Those who evaluate their own knowledge more highly are less likely to search for additional information about GMOs before making a decision and forming an attitude (17). Differences between objective and subjective knowledge appear when people do not have accurate perceptions of how much they actually know (17). Researchers agree that measuring the impact of knowledge on forming an attitude towards GMOs is an important research topic that needs to be explored further (18). Because of contradicting results in previous studies on the impact of knowledge on attitudes towards GMOs (18), the aim of our research was to examine the general attitudes towards GMOs of the Slovenian population and how these attitudes are influenced by knowledge on GMOs. Further, our aim was to contribute to the development of science also by including informal knowledge. Existent research on the impact of knowledge on attitudes towards GMOs mostly analysed objective knowledge gained through formal education. Because (new) media have become important offers of knowledge (19) due to various reasons, mostly because of easy accessibility, individual adaptability and multimedia persuasiveness, we included in our research informal knowledge about basic legal provisions related to GMOs and false messages that were cited as facts in Slovenian media and thus function as "media myths" (20). Thus, the paper aimed to improve understanding of informal channels that form attitudes towards GMOs in the Slovenian population. 


\section{METHODS}

An extensive standardised questionnaire included a set of demographic variables (sex, age, education, type of settlement, region of residence, employment, satisfaction with economic standard, attitudes towards GMOs and knowledge about GMOs). Because even early European studies (21) found that acceptance of GMOs differed based on where biotechnology was used, the attitudes towards GMOs were measured both generally and related to various types (animals, plants, microorganisms), applications (for food and feed, in industry, pharmacy and medicine) and geographical distance (cultivation of GM plants in or outside Slovenia). The questionnaire about knowledge was based on definitions from existing studies on the deficit model of (objective) knowledge from formal education (6, 11 ), supplemented with subjective knowledge (17), knowledge from informal education (information about GMO legislation and media myths). Knowledge about GMOs was measured using five indicators based on true or false statements about GMOs. In the academic literature, these indicators are described and employed as a) scientific facts about GMOs that people can learn through formal education - two false statements: "Ordinary tomatoes do not contain genes while GM tomatoes include genes" and "By eating a GM plant, a person's genes could also be changed" $(5,17) ; b)$ media myths: "GMOs pass from feed into milk and dairy products" and "Because of the cultivation of GMOs, there are more and more allergies in Slovenia" (20); and c) general knowledge about regulation of GMOs - the true statement: "All products that contain more than $0.9 \%$ of GMO in food and feed must be labelled in the EU but not in the USA" (22). Indicators of knowledge do not measure complete knowledge about GMOs but rather knowledge about the five concrete statements. The indicators are founded upon a study by House et al. (16) that draws a distinction between objective and subjective knowledge about GMOs. The measurement of subjective knowledge was enabled by inclusion of a control question in which the respondents were asked to assess their certainty about the correctness of answers given to questions measuring objective knowledge. In this way, it was verified whether there were differences in attitudes with regard to actual (objective) knowledge and self-assessment of one's own knowledge (subjective knowledge).
In January 2012, the Centre for Public Opinion Research conducted a telephone survey about attitudes and knowledge regarding GMOs on a representative sample among the population of Slovenia. To verify differences in attitudes with regard to nominal demographic variables, we performed a non-parametric Kruskal-Wallis test. Linear correlations between attitude and knowledge (objective and subjective) were tested through calculation of the Pearson correlation coefficient $(r)$ and the estimation of a multiple regression model. A total of 446 respondents participated in the survey. In analysing the data, the procedure of weighting was used to correct deviations between the sample and the population. After using weights, the structure of demographic variables was $51 \%$ women and $49 \%$ men; $44.8 \%$ were employed and $21.9 \%$ were unemployed. The largest seent, approximately one third (34.2\%), had a high school education, one fourth (24.4\%) a primary school education, one fifth $(21 \%)$ a vocational school education and a similar share of respondents $(20.4 \%)$ a higher or university education.

\section{RESULTS}

\subsection{Attitudes towards GMOs}

The research showed that the majority of the Slovenian population is strongly opposed to GMOs (Table 1), regardless of type (plants, animals, microorganisms), application (for food and feed, in industry, pharmacy and medicine) or geographical distance (cultivation in or outside Slovenia). Slovenians are most strongly against the genetic modification of animals, which is opposed by $81.4 \%$ of respondents and accepted by only $6 \%$. The highest level of acceptance $(23.5 \%)$ was established in using GMOs for medicines, although even here the share of non-acceptance is high (47.6\%). Slovenians perceive the risks of GMOs more often than the advantages, regardless of the various aspects environmental, health, political, scientific or economic. This is particularly evident in the health area, where the majority $(68.4 \%)$ of respondents emphasise the health risks of GM-food, and only $8.7 \%$ point to advantages. Regarding the use of GM feed for animals and consequent impacts on people, the majority $(69.2 \%)$ of respondents perceive it as risky, while only $9.2 \%$ do not associate the use of GM feed with health risks. 
Table 1. Share of answers about attitudes and perception of risks and advantages of GMOs, $N=446$ (in \%). Tabela 1. Deleži odgovorov o stališčih in percepciji tveganja in koristi GSO, N=446 ( $\mathrm{v} \%$ ).

\begin{tabular}{|c|c|c|c|c|c|c|}
\hline $\begin{array}{l}\text { Attitudes towards ...I } \\
\text { stališča do ... }\end{array}$ & \begin{tabular}{|l|} 
Absolutely \\
disagreel \\
povsem \\
nasprotujem
\end{tabular} & \begin{tabular}{|l|} 
Disagree/ \\
nasprotujem
\end{tabular} & \begin{tabular}{|l} 
Neither- \\
nor/ \\
niti, niti
\end{tabular} & $\begin{array}{l}\text { Agree/ } \\
\text { podpiram }\end{array}$ & \begin{tabular}{|l|} 
Absolutely \\
agree/ \\
povsem \\
podpiram \\
\end{tabular} & $\begin{array}{l}\text { Don't know, } \\
\text { no answer/ } \\
\text { ne vem, b.o. }\end{array}$ \\
\hline $\begin{array}{l}\text { GM animals/ } \\
\text { GS-živali }\end{array}$ & 60.4 & 21.0 & 8.6 & \begin{tabular}{|l|}
2.7 \\
\end{tabular} & 3.3 & 4.0 \\
\hline $\begin{array}{l}\text { use of GMOs for food for people*/ } \\
\text { uporabe GSO za prehrano ljudi }\end{array}$ & 54.2 & 21.4 & 14.6 & 5.3 & 1.0 & \begin{tabular}{|l|}
3.4 \\
\end{tabular} \\
\hline $\begin{array}{l}\text { use of GMOs for feed for animals*/ } \\
\text { uporabe GSO za krmo živali* }\end{array}$ & 55.7 & 22.7 & 9.0 & 9.1 & 0.6 & 2.9 \\
\hline $\begin{array}{l}\text { cultivation of GM plants in Slovenia*/ } \\
\text { pridelave GS-rastlin v Sloveniji* }\end{array}$ & 48.3 & 27.3 & \begin{tabular}{|l|}
13.6 \\
\end{tabular} & 5.7 & \begin{tabular}{|l|l}
1.4 \\
\end{tabular} & 3.8 \\
\hline $\begin{array}{l}\text { cultivation of GM plants outside } \\
\text { Slovenia/ } \\
\text { pridelave GS-rastlin izven Slovenije }\end{array}$ & 45.0 & 25.6 & 14.5 & 4.9 & 3.0 & 7.1 \\
\hline $\begin{array}{l}\text { GM microorganisms/ } \\
\text { GS-mikroorganizmov }\end{array}$ & 50.3 & 16.0 & 11.3 & 7.5 & \begin{tabular}{|l|}
4.4 \\
\end{tabular} & \begin{tabular}{|l|}
10.4 \\
\end{tabular} \\
\hline $\begin{array}{l}\text { GMOs in general*/ } \\
\text { GSO na splošno* }\end{array}$ & 48.8 & 21.7 & \begin{tabular}{|l|l}
19.0 \\
\end{tabular} & 6.0 & 2.5 & 2.0 \\
\hline $\begin{array}{l}\text { GM plants/ } \\
\text { GS-rastlin }\end{array}$ & \begin{tabular}{|l|l|}
49.0 \\
\end{tabular} & 23.3 & \begin{tabular}{|l|l}
15.4 \\
\end{tabular} & 5.7 & 3.8 & 2.9 \\
\hline $\begin{array}{l}\text { use of GMOs in industry/ } \\
\text { uporabe GSO v industriji }\end{array}$ & 34.4 & 20.7 & 20.9 & \begin{tabular}{|l|}
13.1 \\
\end{tabular} & 4.6 & 6.3 \\
\hline $\begin{array}{l}\text { use of GMOs in pharmacy and } \\
\text { medicine/ } \\
\text { uporabe GSO v farmaciji in medicini }\end{array}$ & 27.1 & 20.5 & \begin{tabular}{|l|}
19.7 \\
\end{tabular} & 17.8 & 5.7 & 9.2 \\
\hline $\begin{array}{l}\text { Perception of risks/advantages/ } \\
\text { percepcija tveganja/koristi }\end{array}$ & \begin{tabular}{|l|} 
Very risky/ \\
zelo tvegano
\end{tabular} & \begin{tabular}{|l|} 
Risky/ \\
tvegano
\end{tabular} & \begin{tabular}{|l|} 
Neither- \\
nor/ \\
niti-niti
\end{tabular} & \begin{tabular}{|l|} 
Beneficial/ \\
koristno
\end{tabular} & \begin{tabular}{|l} 
Very \\
beneficial/ \\
zelo \\
koristno
\end{tabular} & $\begin{array}{l}\text { Don't know, } \\
\text { no answer/ } \\
\text { ne vem, b.o. }\end{array}$ \\
\hline $\begin{array}{l}\text { health - GM food for people }{ }^{*} / \\
\text { zdravstveno - GS-hrana za ljudi* }\end{array}$ & 36.8 & 31.6 & \begin{tabular}{|l|}
13.3 \\
\end{tabular} & 5.0 & 3.7 & 9.6 \\
\hline $\begin{array}{l}\text { health - GM feed in animal husbandry*/ } \\
\text { zdravstveno - GS-krma za živali oz. } \\
\text { ljudi }^{*}\end{array}$ & 35.0 & 34.2 & \begin{tabular}{|l|}
13.7 \\
\end{tabular} & \begin{tabular}{|l}
7.2 \\
\end{tabular} & 2.0 & \begin{tabular}{|l|}
7.9 \\
\end{tabular} \\
\hline $\begin{array}{l}\text { Environmental/ } \\
\text { okoljsko }\end{array}$ & 24.0 & 33.2 & 24.0 & 7.0 & 1.2 & \begin{tabular}{|l|l}
10.7 \\
\end{tabular} \\
\hline $\begin{array}{l}\text { political - Slovenia/ } \\
\text { politično - Slovenija }\end{array}$ & 11.4 & \begin{tabular}{|l|l}
19.9 \\
\end{tabular} & \begin{tabular}{|l|l}
18.6 \\
\end{tabular} & 9.7 & 2.9 & 37.5 \\
\hline $\begin{array}{l}\text { Scientific/ } \\
\text { znanstveno }\end{array}$ & \begin{tabular}{|l|}
10.3 \\
\end{tabular} & 24.1 & 27.1 & 13.9 & 3.5 & 21.1 \\
\hline $\begin{array}{l}\text { political - EU/ } \\
\text { politično - EU }\end{array}$ & 7.5 & 16.7 & \begin{tabular}{|l}
19.2 \\
\end{tabular} & 12.3 & 3.3 & 41 \\
\hline $\begin{array}{l}\text { Economic/ } \\
\text { ekonomsko }\end{array}$ & 11.6 & 21.2 & 22.6 & 20.9 & 7.5 & \begin{tabular}{|l|}
16.1 \\
\end{tabular} \\
\hline
\end{tabular}

*Marked variables were combined into Index of attitudes towards health impacts of GMOs.

*Označene spremenljivke smo združili v Indeks stališč do zdravstvenih vplivov GSO. 
Frequency analysis of combined variables, which points to perception of impact of GMOs on an individual's health (health impact), showed that the majority is absolutely opposed $(50.9 \%)$ or opposed $(33.4 \%)$ to GMOs because of health impacts. Approximately one tenth $(12.1 \%)$ are indeterminate, and $3.7 \%$ of respondents do not associate GMOs with risks to their health.

The majority of respondents $(85.2 \%$ of those from a smaller town, $83.5 \%$ of those from a larger town) are opposed to GMOs because of possible health impacts, regardless of settlement type; only slightly fewer opponents come from a larger town. With regard to employment, there is a higher share of opponents among the employed ( $88.1 \%$ against, $4 \%$ supportive to GMOs), while among the unemployed the share of opponents is somewhat lower (67.8\% against, $4.6 \%$ for GMOs). Regarding satisfaction with economic status, a higher share of opponents of GMOs are among the unsatisfied ( $91.4 \%$ negative vs. $1.4 \%$ positive); among those who were satisfied with their economic status, the share of scepticism towards GMOs is lower ( $81.8 \%$ negative vs. $4.1 \%$ positive). Differences in attitudes related to sex reveal a lower share of opponents among men (78.7\%) than among women (88.6\%). A firm attitude absolutely against GMOs is held by more women $(60.1 \%)$ than men $(40.2 \%)$. Men in general more often regard GMOs as a source of health risks than women (5.3\% vs. $2.2 \%$ ). The nonparametric Kruskal-Wallis test showed that between attitudes and the above-mentioned demographic variables, the differences in ranks are statistically significant $(p \leq 0.05)$. The correlation analysis pointed to a statistically significant negative linear correlation between attitudes towards health impacts of GMOs and age $(r=-0.342, p<0.001)$. The older respondents have more negative attitudes towards the health impacts of GMOs.

\subsection{Knowledge about GMOs}

The objective knowledge of the majority of respondents $(59.5 \%)$ is medium (they gave two or three correct answers to five questions). Three tenths of respondents (30.4\%) have weak knowledge about GMOs (they gave one or no correct answers). The smallest share, that is, one tenth of respondents $(10.2 \%)$ proved good knowledge about GMOs (to five questions, they gave four or five correct answers). The research showed that the majority of Slovenians have better objective knowledge on topics linked to formal education and legislation and weaker knowledge regarding myths reported by mass media (Table 2). The majority of respondents (51.8\% and $41.2 \%)$ correctly established that the statements relating to one's formal education ("By eating a GM plant, a person's genes could also be changed" and "Ordinary tomatoes do not contain genes while GM tomatoes include genes") are false. Among them, there was a higher share of those who were convinced that their answers were correct. The share of those who gave false answers to questions from formal education was also high (36.4\% and $39.7 \%$ ). The research revealed similar findings regarding knowledge about legislation, as $44.8 \%$ of respondents knew that in the EU all products that contain more than $0.9 \%$ of GMOs in food or feed must be labelled while in the USA it is not so. Among them, the majority was also convinced that their answers were correct. For this statement, there was the lowest share of those who gave a false answer (15.1\%) and a high share who gave no answer (40\%).

Regarding knowledge about mass media myths about GM food, the research showed weaker objective knowledge in the majority of respondents. The majority $(70.8 \%$ and $76.9 \%)$ incorrectly answered that the statements "GMOs pass from feed into milk and dairy products" and "Because of cultivation of GMOs, there are more and more allergies in Slovenia" are true. Yet the majority among them were convinced that their own answers were correct (43.6\% and 51.6\%). There was a particularly high share who considered that, because of the cultivation of GMOs, there are more and more allergies in Slovenia (76.9\%), which indicates a belief of health (allergologic) risks related to GMOs. 
Table 2. Share of answers to statements about GMOs that measure knowledge, $N=446$ (in \%). Tabela 2. Deleži odgovorov na trditve o GSO, ki merijo znanje, $N=446$ ( $\mathrm{v} \%$ ).

\begin{tabular}{|c|c|c|c|c|c|}
\hline & \begin{tabular}{|l|}
$\begin{array}{l}\text { Gave correct } \\
\text { answer and } \\
\text { was sure }\end{array}$ \\
(objective and \\
subjective \\
knowledge)/ \\
odgovoril \\
pravilno in bil \\
prepričan \\
(objektivno in \\
subjektivno \\
znanje)
\end{tabular} & $\begin{array}{l}\text { Gave correct } \\
\text { answer but } \\
\text { was not sure } \\
\text { (only } \\
\text { objective } \\
\text { knowledge)/ } \\
\text { odgovoril } \\
\text { pravilno, a ni } \\
\text { bil prepričan } \\
\text { (le objektivno } \\
\text { znanje) }\end{array}$ & 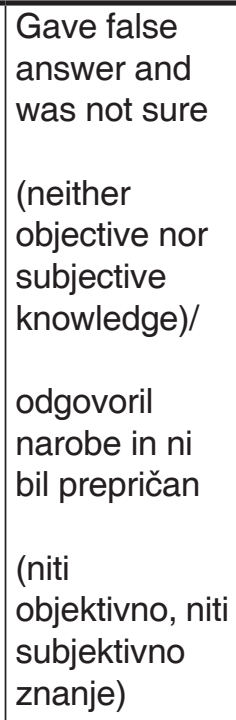 & $\begin{array}{l}\begin{array}{l}\text { Gave false } \\
\text { answer but } \\
\text { was sure }\end{array} \\
\text { (only } \\
\text { subjective } \\
\text { knowledge)/ } \\
\text { odgovoril } \\
\text { narobe, a je } \\
\text { bil prepričan } \\
\text { (le } \\
\text { subjektivno } \\
\text { znanje) }\end{array}$ & $\begin{array}{l}\text { Don't } \\
\text { know, } \\
\text { no } \\
\text { answer/ } \\
\text { ne vem, } \\
\text { b.o. }\end{array}$ \\
\hline $\begin{array}{l}\text { "By eating a GM plant, a person's } \\
\text { genes could also be changed."/ } \\
\text { "Če pojemo rastlino, ki je GS, se } \\
\text { spremenijo tudi naši, človeški geni.« }\end{array}$ & 29.9 & 21.9 & 18.2 & 18.2 & 11.8 \\
\hline $\begin{array}{l}\text { "All products that contain more than } \\
0.9 \% \text { of GMO in food and feed must be } \\
\text { labelled in the EU, but not in the USA."/ } \\
\text { „V EU morajo biti produkti, ki vsebujejo } \\
\text { več kot } 0,9 \% \text { GSO v hrani in krmi, } \\
\text { označeni, v ZDA pa ne.« }\end{array}$ & 24.9 & \begin{tabular}{|l|l}
19.9 \\
\end{tabular} & 7.9 & 7.2 & 40 \\
\hline $\begin{array}{l}\text { "Ordinary tomatoes do not contain } \\
\text { genes while GM tomatoes include } \\
\text { genes."/ } \\
\text { »Navaden paradižnik ne vsebuje } \\
\text { genov, medtem ko gensko spremenjeni } \\
\text { paradižnik gene vsebuje.« }\end{array}$ & 25.5 & 15.7 & \begin{tabular}{|l|l|}
13.8 \\
\end{tabular} & 25.9 & 19.1 \\
\hline $\begin{array}{l}\text { "GMOs pass from feed into milk and } \\
\text { dairy products."/ } \\
\text { »GSO iz krme prehaja v mleko in } \\
\text { mlečne izdelke.« }\end{array}$ & 9.6 & 9.6 & 27.2 & 43.6 & 10 \\
\hline $\begin{array}{l}\text { "Because of cultivation of GMOs } \\
\text { there are more and more allergies in } \\
\text { Slovenia."/ } \\
\text { "Zaradi pridelave GSO je v Sloveniji } \\
\text { vedno več alergij.« }\end{array}$ & 7.3 & \begin{tabular}{|l|}
8.1 \\
\end{tabular} & 25.3 & 51.6 & 7.7 \\
\hline
\end{tabular}




\subsection{Correlation of objective/subjective knowledge with index of attitudes and firmness of attitudes towards health impacts of GMOs}

The correlation analysis (Table 3 ) showed that the respondents with better objective knowledge (who gave more correct answers) had less firm ( $r=-0.204)$ and more positive $(r=+0.225)$ attitudes towards the health impacts of GMOs (see combined variables in Table 1) and vice versa. The respondents who had weaker objective knowledge had firmer and more negative attitudes towards the health impacts of GMOs. The respondents with better objective knowledge (who gave more correct answers) had weaker subjective knowledge (they were mostly not sure about the correctness of their answers) and vice versa. The respondents with weaker objective knowledge (who gave more false answers) had better subjective knowledge (they were sure about their answers). All mentioned statistically significant linear correlations are very weak. The correlation analysis showed no statistically significant linear correlations between subjective knowledge and attitudes and firmness of attitudes towards the health impacts of GMOs. However, variance analysis of one factor showed that the respondents with subjective knowledge and a lack of objective knowledge had, on average, a) more negative attitudes than those who lacked subjective knowledge, regardless of having objective knowledge $(p=0.015)$, and $b)$ firmer attitudes than those who lacked both objective and subjective knowledge $(p=0.014)$. Thus, those who were unsure about the correctness of their knowledge had more positive and less firm attitudes.

Table 3. Correlation matrix for correlation between knowledge (objective and subjective) and attitudes and firmness of attitudes towards health impacts of GMOs.

Tabela 3. Korelacijska matrika za povezanost med znanjem (objektivnim in subjektivnim) ter stališči in trdnostjo stališč do zdravstvenih vplivov GSO.

\begin{tabular}{|c|c|c|c|c|}
\hline $\begin{array}{l}\text { Pearson's r/ } \\
\text { Pearsonov } r\end{array}$ & $\begin{array}{l}\text { Objective } \\
\text { knowledge/ } \\
\text { objektivno } \\
\text { znanje } \\
\end{array}$ & $\begin{array}{l}\text { Subjective } \\
\text { knowledge/ } \\
\text { subjektivno } \\
\text { znanje } \\
\end{array}$ & $\begin{array}{l}\text { Index of attitudes } \\
\text { towards health } \\
\text { impacts of GMOs/ } \\
\text { indeks stališč do } \\
\text { zdravstvenih vplivov } \\
\text { GSO } \\
\end{array}$ & \begin{tabular}{|l} 
Index of firmness of \\
attitudes towards health \\
impacts of GMOs/ \\
trdnost indeksa stališč \\
do zdravstvenih vplivov \\
GSO \\
\end{tabular} \\
\hline $\begin{array}{l}\text { Objective knowledge/ } \\
\text { objektivno znanje }\end{array}$ & 1 & & & \\
\hline $\begin{array}{l}\text { Subjective knowledge/ } \\
\text { subjektivno znanje }\end{array}$ & $-0.213^{\star *}$ & 1 & & \\
\hline $\begin{array}{l}\text { Index of attitudes towards } \\
\text { health impacts of GMOs/ } \\
\text { indeks stališč do zdravstvenih } \\
\text { vplivov GSO }\end{array}$ & $0.225^{\star *}$ & -0.145 & 1 & \\
\hline $\begin{array}{l}\text { Index of firmness of attitudes } \\
\text { towards health impacts of } \\
\text { GMOs/ } \\
\text { trdnost indeksa stališč do } \\
\text { zdravstvenih vplivov GSO }\end{array}$ & $-0.204^{\star *}$ & 0.098 & $-0.818^{\star \star}$ & 1 \\
\hline
\end{tabular}


Multiple regression was conducted to determine the best linear combination of Objective and Subjective knowledge for predicting attitudes towards the health impacts of GMOs. This combination of variables significantly predicted attitudes ( $F=5.673, p=0.004)$, with two variables significantly contributing to the prediction. $5 \%$ of the variance of attitudes was explained by the model (Adj. $R^{2}=0.05$ ). The beta weights suggest that the impact of objective knowledge on an individual's attitudes towards $\mathrm{GMOs}$ is positive $(B=0.121, \beta=0.203$, $\mathrm{p}=0.007$ ).

\section{DISCUSSION AND CONCLUSION}

A comparison with results of previous representative research (conducted in Slovenia and internationally) shows that attitudes towards GMOs have become even more negative among Slovenians (5-9). A comparison between our results and results from the last Eurobarometer survey on using GMOs for food for people (5) showed that $23 \%$ of EU respondents do not refuse GM food on principle, whereas the share of Slovenians with such an attitude is much lower (6.3\%). The majority of Slovenians have homogenous attitudes against GMOs (84.3\% negative vs. $3.7 \%$ positive), which demonstrates an increased negative attitude if compared to previous Slovenian (7-9) and European (5, 6) studies. In 2007 , for example, $79.4 \%$ of respondents perceived negative impacts of GMOs on an individual's health, while $6.1 \%$ did not associate GMOs as risky for their health (9).

According to answers to particular statements that measured knowledge in our research, the majority of respondents $(51.8 \%)$ correctly answered that the statement that a person's genes could be changed by eating a GM plant is false, and the majority among them were firmly convinced that their own answer was correct. The result is not surprising as this statement is taken from old surveys $(5,17)$ that have already been performed for over a decade, which increases the possibility that the respondents have heard about the correct answer before. But compared to the representative Eurobarometer research, average Slovenians have weaker knowledge about GMOs (5). By comparison, $54 \%$ of answers were correct among Europeans in 2005 (5) Similarly, the statement that ordinary tomatoes do not contain genes while GM tomatoes do (5), which has been a regular indicator of knowledge in Eurobarometer surveys, showed that the number of correct answers increases through the years: $35 \%$ in 1997 and $2000,36 \%$ in the next survey from
2003 and $41 \%$ in the survey from 2005 . The latter result is comparable to the result of our research in which $41.2 \%$ of respondents have the right answer (objective knowledge), and only slightly less (39.7\%) still believe that only GM tomatoes contain genes. Among them, those who have a firm belief in the correctness of their (false) answers prevail. The result indicates that even though knowledge has improved (5), a lot of Slovenians still show poor knowledge about genes in organisms. According to our indicators for knowledge, Slovenians have weaker objective knowledge about myths from mass media, which are their most frequent source of information. For both false statements ("GMOs pass from feed into milk and dairy products" and "Because of the cultivation of GMOs, there are more and more allergies in Slovenia"), which often appear in Slovenian mass media (20), the majority of respondents believed that they were true, and they were also very convinced about the correctness of their answer. Thus, the mass media are not only the key informers of Slovenians about GMOs but also the crucial carriers of ignorance about GMOs.

A comparison with other studies' results on correlation between knowledge and attitudes towards GMOs (1016) reveals that our results are consistent with findings that better (objective) knowledge increases acceptance of GMOs $(10,11)$. The results of our study do not support the findings that better knowledge influences the formation of clearer prevailing attitudes (13-16). In particular, our research showed that those with more positive and less firm attitudes towards GMOs have somewhat better objective knowledge.

Furthermore, our research confirmed that it is less likely for people with a higher self-assessment of knowledge to search for additional information on GMOs before they form an attitude (17). Thus, in exploring relationships between attitudes and knowledge regarding GMOs, it is important to distinguish between objective and subjective knowledge (17). This means that knowledge has a relevant role in building attitudes towards the perceived impact of GMOs on an individual's health. Therefore, health care practitioners and lectures of natural sciences should pay much more attention to education and information at various levels. At the level of school education, they should be concerned with education of children and young people, for example, revising the primary and secondary school curriculum in the field of natural sciences. Since news media are the main sources of information about GMOs for the majority of the Slovenian population, more attention should also be paid to educating and informing journalists. Health care practitioners should present them the key current 
research findings on public health concerns. Effort should also be placed into the education of experts in order to improve their communication with journalists, such as university scientists in the field of biotechnology and agriculture, who are rarely journalists' source of information and do not know how the complexities of GMOs can be communicated more effectively using narrative, analogies, etc. (20). In order to increase the knowledge and awareness of the Slovenian population about GMOs, public health practitioners, lecturers of natural sciences and others should also provide all key information about GMOs, for example, in form of publications on the internet. To the broader public, they should present information on how the safety assessment procedure, including the health risk assessment, is carried out before GMOs are placed on the market and the main institutions that are involved in this procedure (e.g. EFSA).

Because our research showed that respondents have different knowledge about particular statements about GMOs, in the future it would be necessary to conduct more in-depth research on knowledge on respondents about various fields of GMOs, with an emphasis on the health field. It would also be useful to research respondents' sources of knowledge and trust in them.

\section{References}

1. Marks LA, Kalaitzandonakes N. Mass media communications about agrobiotechnology. AgBioForum 2001; 4: 199-208.

2. Paparini A, Romano-Spica V. Public health issues related with the consumption of food obtained from genetically modified organism. Biotechnol Annu Rev 2004; 10: 85-122.

3. Regulation (EC) No. $1829 / 2003$ of the European parliament and of the council of 22 September 2003. Off J EU 268/1.

4. EFSA panel on genetically modified organisms (GMO); scientific opinion on guidance for risk assessment of food and feed from genetically modified plants. EFSA J 2011; 9: 2150. Available online: www.efsa.europa.eu/efsajournal.htm
5. Eurobarometer 64.3. The Europeans and biotechnology in 2005: patterns and trends. Bruxelles: TNS, 2006.

6. Eurobarometer 73.1. Biotechnology. Bruxelles: TNS, 2010.

7. Umanotera. Telefonska mnenjska raziskava o GSO. Slovenska fundacija za trajnostni razvoj, 2002.

8. Kirinčič S, Tivadar B. Odnos prebivalcev Slovenije do uživanja gensko spremenjene hrane. Ljubljana: Biotehniška fakulteta, 2005.

9. ZPS. Javno mnenjska anketa o gensko spremenjenih organizmih. Ljubljana: Zveza potrošnikov Slovenije, 2007.

10. Boccaletti S, Moro D. Consumer willingness-to-pay for GM food products in Italy. AgBioForum 2000; 3: 259-267.

11. Allum N, Sturgis P, Tabourazi D, Brunton-Smith I. Science knowledge and attitudes across cultures: a meta-analysis. Public Underst Sci 2008; 17: 35-54.

12. Fischhoff $B$, Fischhoff I. Publics' opinions about biotechnologies. AgBioForum 2001; 4: 155-162.

13. Ekborg M. Opinion building on a socioscientific issue. J Biolog Educ 2008; 42: 60-65.

14. Morris SH, Adley CC. Genetically modified food issues: attitudes of Irish university scientists. Brit Food J 2000; 102: 669-691.

15. Ronteltap A, van Trijp JCM, Reneb RJ, Frewer LJ. Consumer acceptance of technology-based food innovations: lessons for the future of nutrigenomics. Appetite 2007; 49: 1-7.

16. Scholderer J, Frewer LJ. The biotechnology communication paradox. J ConsumPolicy 2003; 26: 125-157.

17. House L, Lusk J, Jaeger S, Traill WB, Moore M, Valli C, Morrow $B$, Yee WMS. Objective and subjective knowledge. AgBioForum 2005; 7: 113-123.

18. Prokop P, Leskova A, Kubiatko M, Diran C. Slovakian student's knowledge of and attitudes toward biotechnology. Int J Sci Educ 2007; 29: 895-907.

19. Thomas, M. Digital education. New York: Palgrave Macmillan, 2011.

20. Erjavec K, Zajc J. Stališča slovenskih medijev o gensko spremenjenih organizmih. Družboslovne razprave 2011; 27: 25-43.

21. Hamstra IA. Public opinion about biotechnology. The Hague: Cambridge Biomedical Consultants Limited; 1998.

22. EFSA. Genetically modified organisms. 2011. Available from: http://www.efsa.europa.eu/en/otopics/topic/o.htm 